\title{
SNAl1 is critical for the aggressiveness of prostate cancer cells with low E-cadherin
}

\author{
Gagan Deep ${ }^{1,2^{*}}$, Anil K Jain ${ }^{1}$, Anand Ramteke ${ }^{1,3}$, Harold Ting ${ }^{1}$, Kavitha C Vijendra', Subhash C Gangar ${ }^{1}$,
} Chapla Agarwal ${ }^{1,2}$ and Rajesh Agarwal $1^{1,2^{*}}$

\begin{abstract}
Background: A better molecular understanding of prostate carcinogenesis is warranted to devise novel targeted preventive and therapeutic strategies against prostate cancer (PCA), a major cause of mortality among men. Here, we examined the role of two epithelial-to-mesenchymal transition (EMT) regulators, the adherens junction protein E-cadherin and its transcriptional repressor SNAl1, in regulating the aggressiveness of PCA cells.

Methods: The growth rate of human prostate carcinoma PC3 cells with stable knock-down of E-cadherin (ShEC-PC3) and respective control cells (Sh-PC3) was compared in MTT and clonogenic assays in cell culture and in nude mouse xenograft model in vivo. Stemness of ShEC-PC3 and Sh-PC3 cells was analyzed in prostasphere assay. Western blotting and immunohistochemistry (IHC) were used to study protein expression changes following E-cadherin and SNAl1 knock-down. Small interfering RNA (siRNA) technique was employed to knock- down SNAl1 protein expression in ShEC-PC3 cells.

Results: ShEC-PC3 cells exerted higher proliferation rate both in cell culture and in athymic nude mice compared to Sh-PC3 cells. ShEC-PC3 cells also formed larger and a significantly higher number of prostaspheres suggesting an increase in the stem cell-like population with E-cadherin knock-down. Also, ShEC-PC3 prostaspheres disintegration, in the presence of serum and attachment, generated a bigger mass of proliferating cells as compared to Sh-PC3 prostaspheres. Immunoblotting/IHC analyses showed that E-cadherin knock-down increases the expression of regulators/biomarkers for stemness (CD44, cleaved Notch1 and Egr-1) and EMT (Vimentin, pSrc-tyr416, Integrin $\beta 3$, $\beta$-catenin, and NF-KB) in cell culture and xenograft tissues. The expression of several bone metastasis related molecules namely CXCR4, UPA, RANKL and RunX2 was also increased in ShEC-PC3 cells. Importantly, we observed a remarkable increase in SNAI1 expression in cytoplasmic and nuclear fractions, prostaspheres and xenograft tissues of ShEC-PC3 cells. Furthermore, SNAl1 knock-down by specific siRNA strongly inhibited the prostasphere formation, clonogenicity and invasiveness, and decreased the level of pSrc-tyr416, total Src and CD44 in ShEC-PC3 cells. Characterization of RWPE-1, WPE1-NA22, WPE1-NB14 and DU-145 cells further confirmed that low E-cadherin is associated with higher SNAI1 expression and prostasphere formation.
\end{abstract}

Conclusions: Together, these results suggest that E-cadherin loss promotes SNAI1 expression that controls the aggressiveness of PCA cells.

Keywords: Prostate cancer, E-cadherin, SNAI1, Stemness, EMT

\footnotetext{
* Correspondence: Gagan.deep@ucdenver.edu; Rajesh.agarwal@ucdenver.edu

'Department of Pharmaceutical Sciences, Skaggs School of Pharmacy and

Pharmaceutical Sciences, San Diego, USA

${ }^{2}$ University of Colorado Cancer Center, University of Colorado Denver,

Aurora, Colorado, USA

Full list of author information is available at the end of the article
}

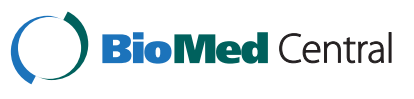

(c) 2014 Deep et al.; licensee BioMed Central Ltd. This is an Open Access article distributed under the terms of the Creative Commons Attribution License (http://creativecommons.org/licenses/by/2.0), which permits unrestricted use, distribution, and reproduction in any medium, provided the original work is properly credited. The Creative Commons Public Domain Dedication waiver (http://creativecommons.org/publicdomain/zero/1.0/) applies to the data made available in this article, unless otherwise stated. 


\section{Background}

Prostate cancer (PCA) is the most common non-cutaneous cancer, and is the second leading cause of cancer-related deaths in American men. According to the American Cancer Society, in 2013, there will be an estimated 238,590 new cases and 29,720 deaths from PCA in the United States [1]. Patients with localized PCA have a high 5-year survival rate and a relatively low mortality to incidence ratio compared to other cancer types [2]. However, in patients with clinically detectable metastasis, the median survival is reduced to only $12-15$ months; therefore, metastasis is the main cause of high mortality among PCA patients [2-4]. PCA cells metastasize to several organs; however, bone is the most frequent site for metastasis [3,5]. Patients with bone metastasis suffer extreme bone pain, spinal-cord compression and fractures [6-8]. In addition, replacement of bone marrow by growing PCA cells disrupts normal haematopoiesis, causing anemia and enhanced susceptibility to infections [7]. Therefore, a better understanding of the early events associated with PCA metastasis is warranted to lower mortality and improve patient's quality of life.

Now it is known that PCA metastasis involves multiple steps including the acquisition of invasiveness through 'EMT' (epithelial to mesenchymal transition), access to systemic blood or lymphatic systems (intravasation), survival in the circulation, arrest in the microvasculature and subsequent extravasation, and growth at distant organs [9]. Among these events, EMT has often been described as absolutely necessary and indispensable for metastasis $[9,10]$. During EMT, cancer cells shed their epithelial features, detach from epithelial sheets and undergo cytoskeletal changes towards a 'mesenchymal phenotype' and acquire a high degree of motility and invasiveness [10,11]. Recent studies have suggested that EMT not only enhances invasiveness and migratory potential but also confers several aggressive attributes to cancer cells such as enhanced stemness, drug and anoikis resistance, etc. [12-14]; and that these features could provide a survival advantage to cancer cells during the arduous metastasis journey from primary organs to distant metastatic sites. Therefore, understanding and targeting the role of EMT regulators in conferring an aggressive phenotype to PCA cells could be useful in effectively inhibiting metastatic progression.

The molecular regulation of EMT is extremely complex and involves numerous interconnected as well as independent pathways and signaling molecules $[10,11,15]$. However, several of these pathways converge together to downregulate the expression of adherens junction molecule E-cadherin [16]. E-cadherin is a transmembrane glycoprotein that regulates cell-cell adhesion, cell polarity and shape through its interactions with E-cadherin molecules on adjacent cells as well as with the actin microfilament network via catenins ( $\alpha, \beta$ and p120) [16]. The loss of
E-cadherin frees catenins from the membranous pool, thus making them available for nuclear signaling, which then promote cancer cell proliferation, invasiveness and EMT $[10,17]$. E-cadherin expression is regulated through a combination of genetic, epigenetic, transcriptional and post-transcriptional mechanisms $[10,16]$. Major transcriptional repressors of E-cadherin are zinc finger family members SNAI1 (SNAIL1 in drosophila) and Slug, the basic helix-loop-helix factors E47 and Twist, and twohanded zinc factors ZEB1 and SIP1 [10]. Importantly, the loss of E-cadherin function has been implicated in the progression and metastasis of several malignancies including PCA $[18,19]$. Furthermore, reduced E-cadherin expression has been correlated with higher tumor grade and poor prognosis in PCA patients [20-23]. However, the molecular changes associated with E-cadherin loss that are responsible for PCA aggressiveness are still not clear. Results from the present study suggest that E-cadherin loss could enhance proliferation and stemness in PCA cells through altering the expression of several signaling molecules but mainly through its transcriptional repressor SNAI1.

SNAI1 is one of the master EMT regulators and is a promoter of metastasis, that represses the expression of several epithelial markers (E-cadherin, claudin, occludin, etc.) and enforces a mesenchymal phenotype by promoting the expression of mesenchymal genes (fibronectin, vimentin, $\alpha$-SMA etc.) $[10,24,25]$. SNAI1 is overexpressed in several cancer cells including PCA where it is suggested to be upregulated at early stages of PCA development [26]. High SNAI1 expression in tumors often correlates with disease aggressiveness and poor prognosis $[23,27,28]$. SNAI1 has been implicated in cancer cell survival, cell cycle regulation, apoptosis evasion, cell adhesion, neuroendocrine differentiation, and chemoresistance [24,25]. In the present study, we analyzed the role of SNAI1 in the aggressiveness of PCA cells with low E-cadherin expression (via Stable E-cadherin knock-down). Our results for the first time showed that SNAI1 could control the clonogenicity, stemness and invasiveness of PCA cells with low E-cadherin expression.

\section{Results}

\section{E-cadherin knock-down increases proliferation of human PCA PC3 cells}

First we analyzed the effect of E-cadherin loss on the proliferation of PC3 cells where ShEC-PC3 cells with Ecadherin knock-down showed higher proliferation at 24, 48, and 72 hrs after seeding compared to vector control Sh-PC3 cells (Figure 1A). MTT assay results were further confirmed in a clonogenic assay which showed that Ecadherin knockdown significantly $(p \leq 0.001)$ enhanced the clonogenicity of PC3 cells (Figure 1B). Next, ShEC-PC3 and Sh-PC3 cells were subcutaneously injected in athymic male nude mice to compare their in vivo growth rate. As 


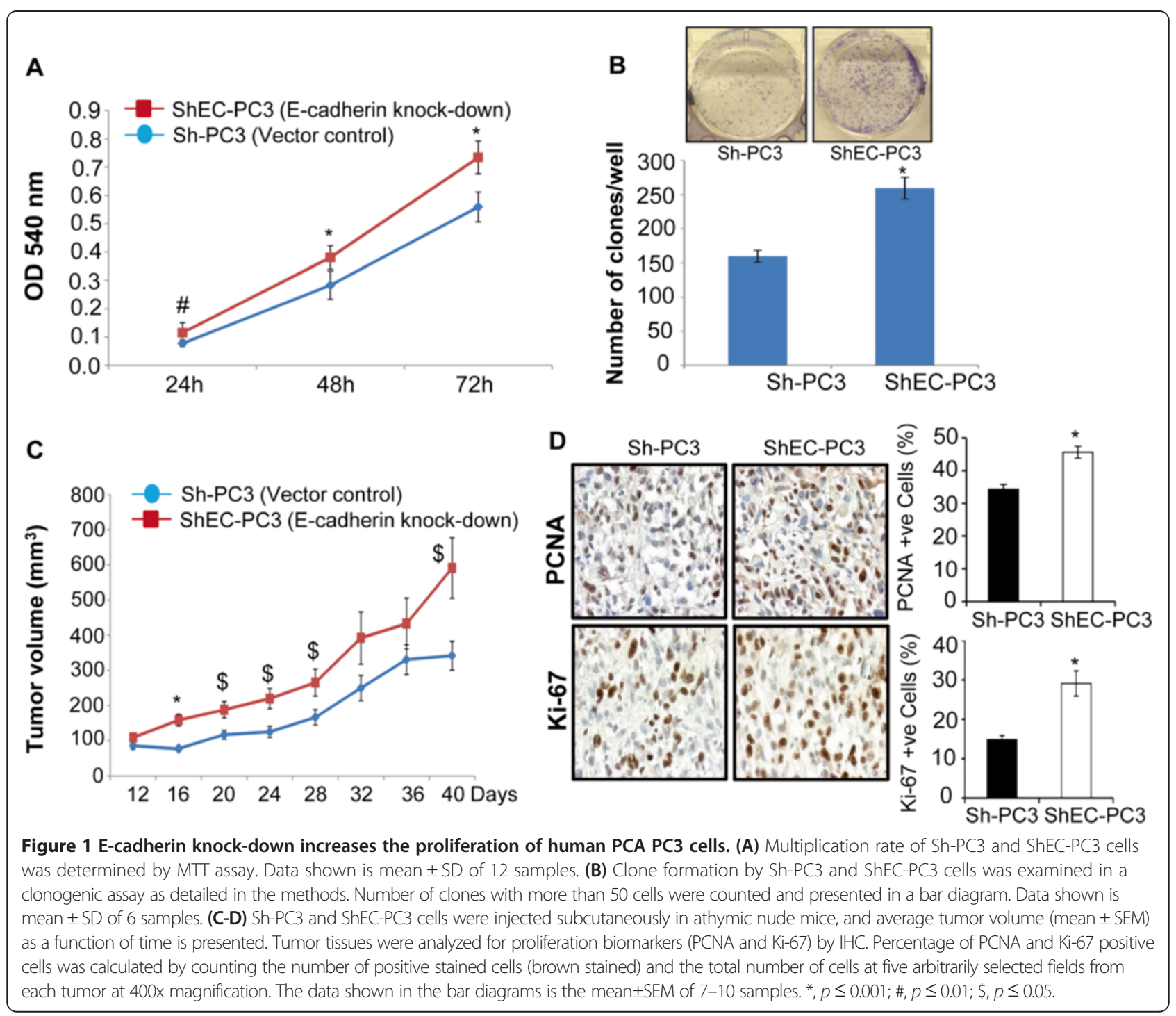

shown in Figure 1C, both Sh-PC3 and ShEC-PC3 cells formed xenografts, however, the tumor volume was consistently higher in ShEC-PC3 cells compared to Sh-PC3 cells. At the end of the study, xenograft tissues were analyzed for proliferation biomarkers (PCNA and Ki-67) by IHC. ShEC-PC3 tumors showed a higher expression of both PCNA and Ki-67 positive cells (Figure 1D), suggesting an increased proliferation rate in vivo. Taken together, these results suggested that E-cadherin knockdown increases the proliferation rate of PC3 cells both in vitro and in vivo.

\section{E-cadherin knock-down enhances the stemness of human PCA PC3 cells}

Next we examined the effect of E-cadherin knock-down on the stemness of PCA cells in a prostasphere assay. The prostasphere assay is considered the 'gold standard' to determine the self-renewal capability of a stem-like cell population (CSC) in cell culture [29-31]. This assay is based upon the principle that only CSC can survive and grow without attachment in the absence of serum. As shown in Figure 2A, ShEC-PC3 cells formed a significantly $(\mathrm{p} \leq 0.001)$ higher number and bigger sized prostaspheres compared to Sh-PC3 cells. These results suggested that E-cadherin knock-down increases the stemness in PC3 cells.

We also analyzed the disintegration or differentiation of prostaspheres in the presence of attachment with or without the addition of serum. Prostaspheres were pipetted and re-plated on normal attachment culture plates with or without $10 \%$ FBS. In the absence of serum, both ShEC-PC3 and Sh-PC3 prostaspheres attached to the bottom of the plate but their disintegration was hardly visible even after 5 days. However, in the presence of serum both 


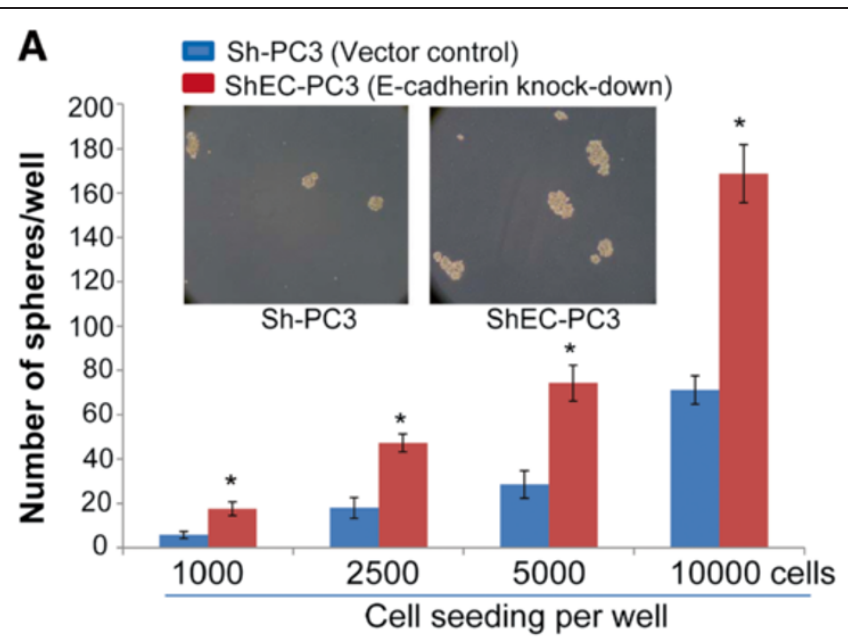

B

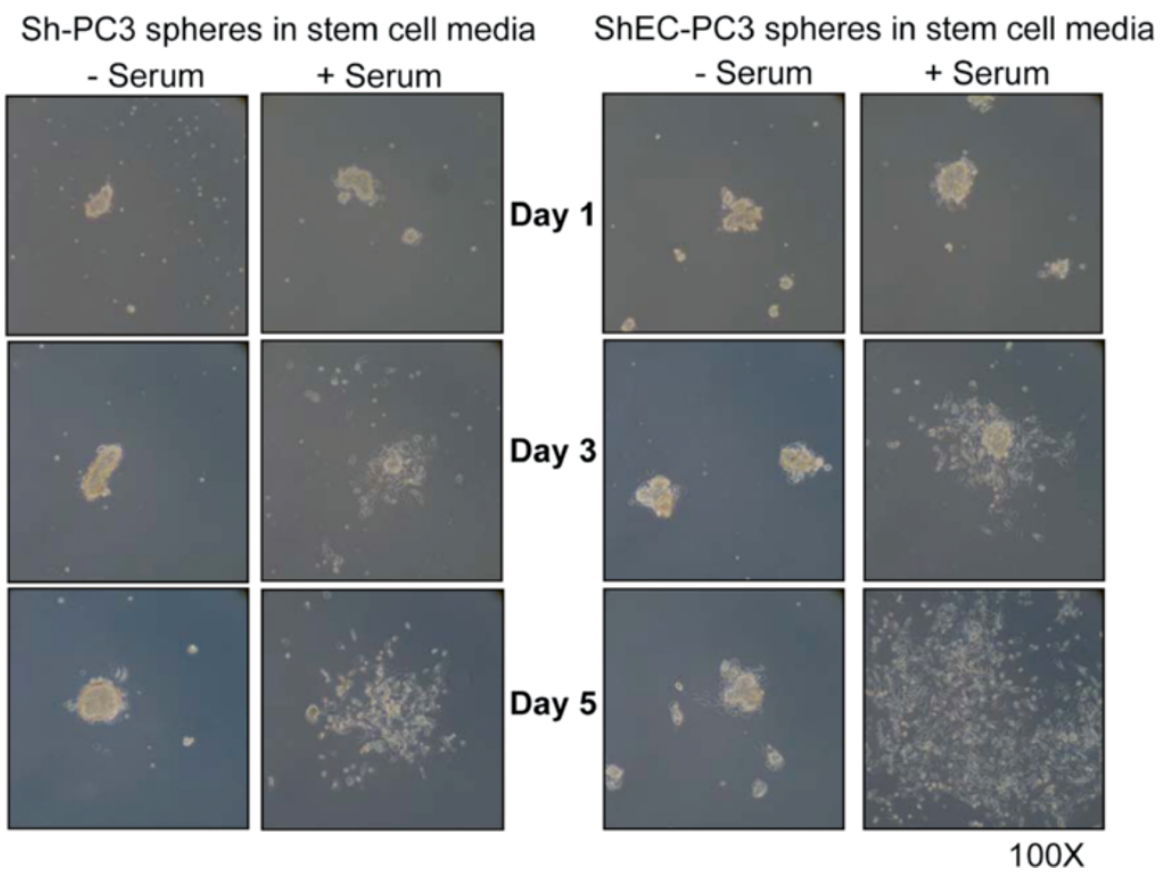

Figure 2 E-cadherin knock-down enhances the stemness of human PCA PC3 cells. (A-B) Sh-PC3 or ShEC-PC3 cells were plated on 6 well Corning ultra-low attachment plates in DMEM/F-12(Ham) media containing supplements B27 and N2. Prostasphere formation was measured after 5 days. Thereafter, prostaspheres were collected and plated on normal cell culture plate with or without serum and monitored for 5 days. Representative pictures are shown for prostaspheres' state at day 1, day 3 and day 5 . Data shown is mean \pm SD of $3-6$ samples. * $p \leq 0.001$.

Sh-PC3 and ShEC-PC3 cells disintegrated into bulk of growing cells; though, in general, ShEC-PC3 prostaspheres generated a bigger mass of growing bulk cells compared to Sh-PC3 prostaspheres (Figure 2B).

\section{E-cadherin knock-down increases the expression of stemness, EMT, and bone metastasis biomarkers in human PCA PC3 cells both in vitro and in vivo}

Next, we analyzed the effect of E-cadherin knock down on stemness and mesenchymal biomarkers in human PCA PC3 cells. Western blot analysis showed that E-cadherin knock-down resulted in increased expression of CD44 and cleaved Notch1 in ShEC-PC3 cells (Figure 3A), which are well known biomarkers for stemness [32-34]. E-cadherin knock-down also increased Egr-1 expression (Figure 3A), which is a regulator of CD44 promoter activity [35]. Furthermore, E-cadherin knock-down resulted in a strong increase in EMT biomarkers, the intermediate filament protein Vimentin and Integrin $\beta 3$ expression (Figure 3A). However, E-cadherin knock-down resulted in only a slight or no significant increase in the expression of other cadherins namely N-cadherin and OB-cadherin (Figure 3A). 


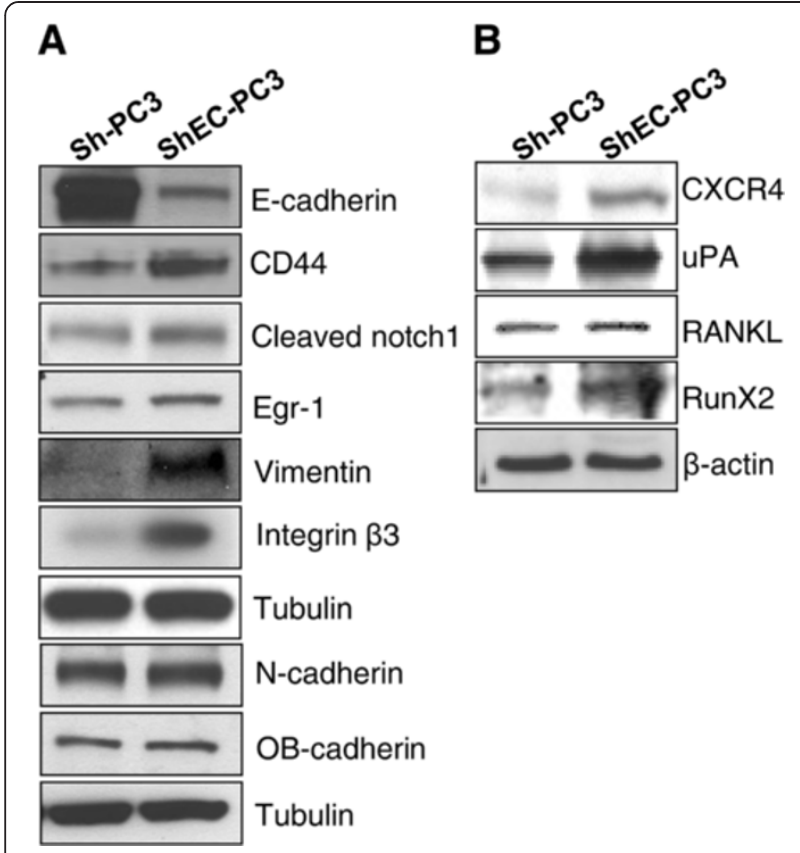

Figure $3 \mathrm{E}$-cadherin knock-down increases the expression of stemness, EMT, and bone metastasis biomarkers in PC3 cells. (A-B) Sh-PC3 or ShEC-PC3 cells were collected at similar confluency and total cell lysates were prepared and analyzed for the protein expression of E-cadherin, CD44, cleaved Notch-1, Egr-1, Vimentin, Integrin $\beta 3$, N-cadherin, OB-cadherin, CXCR4, UPA, RANKL, and RunX2. Tubulin and $\beta$-actin were used as loading controls.

Besides, we have earlier reported a strong increase in the levels of phosphorylated pSrc-tyr416 following E-cadherin knock-down in PC3 cells [36], a kinase associated with increased PCA invasiveness and bone metastasis [37]. E-cadherin knock-down also increased the expression of several other proteins that are important in bone metastasis. As shown in Figure 3B, ShEC-PC3 cells showed higher expression of CXCR4, which is known to play an important role in the migration of PCA cells towards the chemotactic signal (SDF1 $\alpha$ ) secreted by bone endothelial cells $[8,38]$. We also observed increased expression of uPA, RANKL and RunX2, which are considered important for initiating/promoting osteoclastogenesis in bone by PCA cells (Figure 3B) $[7,8]$. Next, we examined the expression of the above mentioned biomarkers in ShEC-PC3 and Sh-PC3 tissues from the xenograft experiment (Figure 1C). As shown in Figure 4, ShEC-PC3 xenograft tissues showed low E-cadherin level but exhibited significantly higher expression of CD44, Notch1, pSrc-tyr416, $\beta$-catenin, CXCR4 and RANKL compared to Sh-PC3 xenograft tissues.

\section{E-cadherin knock-down increases SNAI1 expression in human PCA PC3 cells both in vitro and in vivo}

Next, we examined the expression of several transcriptional factors (SNAI1, $\beta$-catenin, and NF-kB) in Sh-PC3 and ShEC-PC3 cells. We observed a strong increase in the expression of SNAI1 in both cytoplasmic and nuclear fractions of ShEC-PC3 cells compared to Sh-PC3 cells (Figure 5A). However, we observed only a modest increase in nuclear $\beta$-catenin and a slight increase in nuclear NF-kB subunit p65 expression without significant changes in the cytoplasmic $\beta$-catenin and p65 expression between ShEC-PC3 and Sh-PC3 cells (Figure 5A). Importantly, we also observed a strong increase in SNAI1 expression in the prostaspheres formed by ShEC-PC3 cells compared to Sh-PC3 cells (Figure 5B). Furthermore, SNAI1 expression was also increased in ShEC-PC3 xenograft tissues both in terms of increase in the overall immunoreactivity score as well as the percentage of SNAI1-positive cells (Figure 5C).

\section{SNAI1 is critical for the stemness, clonogenicity and invasiveness of ShEC-PC3 cells}

Since we observed a strong increase in SNAI1 expression following E-cadherin knock-down, we next examined whether the increase in SNAI1 controls the stemness, clonogenicity and invasiveness of ShEC-PC3 cells. Accordingly, we knocked-down SNAI1 expression in ShEC-PC3 cells using SNAI1 specific siRNA and performed prostasphere, clonogenic and invasion assays. As shown in Figure 6A-6C, SNAI1 knock-down strongly decreased the number as well as size of prostaspheres and clones ( $\geq 50$ cells) $(p \leq 0.001)$. SNAI1 knock-down also compromised the invasiveness of ShEC-PC3 cells $(p \leq 0.001)$. Furthermore, SNAI1 knock-down resulted in decreased pSrctyr416, Src and CD44 levels, suggesting a role for SNAI1 in regulating their expression. These results confirmed the central role of SNAI1 in controlling stemness, clonogenicity, and invasiveness in ShEC-PC3 cells.

\section{Low E-cadherin is associated with high SNAI1 and prostasphere formation}

Next, we employed 4 cell lines (RWPE-1, WPE1-NA22, WPE1-NB14 and DU-145) and compared their E-cadherin and SNAI1 expression as well as capability to form prostaspheres. RWPE-1 is a non-tumorigenic HPV18 immortalized cell line derived from peripheral zone of an adult human prostate [39]. WPE1-NA22 and WPE1-NB14 were derived from RWPE-1 following 50 and $100 \mu \mathrm{g} / \mathrm{ml}$ MNU (N-methyl-N-nirtosourea) exposure, respectively [39]. These cell lines have been well characterized [39], and WPE1NB14 cells are considered more aggressive than WPE1NA22 cells in terms of their proliferation, invasiveness and xenograft formation in vivo [39]. DU-145 is an androgenindependent human PCA cell line derived from brain metastasis. Together, these cell lines represent various stage of PCA development i.e. from normal to advanced metastatic stage. Immunoblot analysis showed low Ecadherin expression in the membrane fraction of DU-145 and WPE1-NB14 cells compared with WPE1-NA22 and RWPE-1 cells (Figure 7A). Relatively low E-cadherin was 


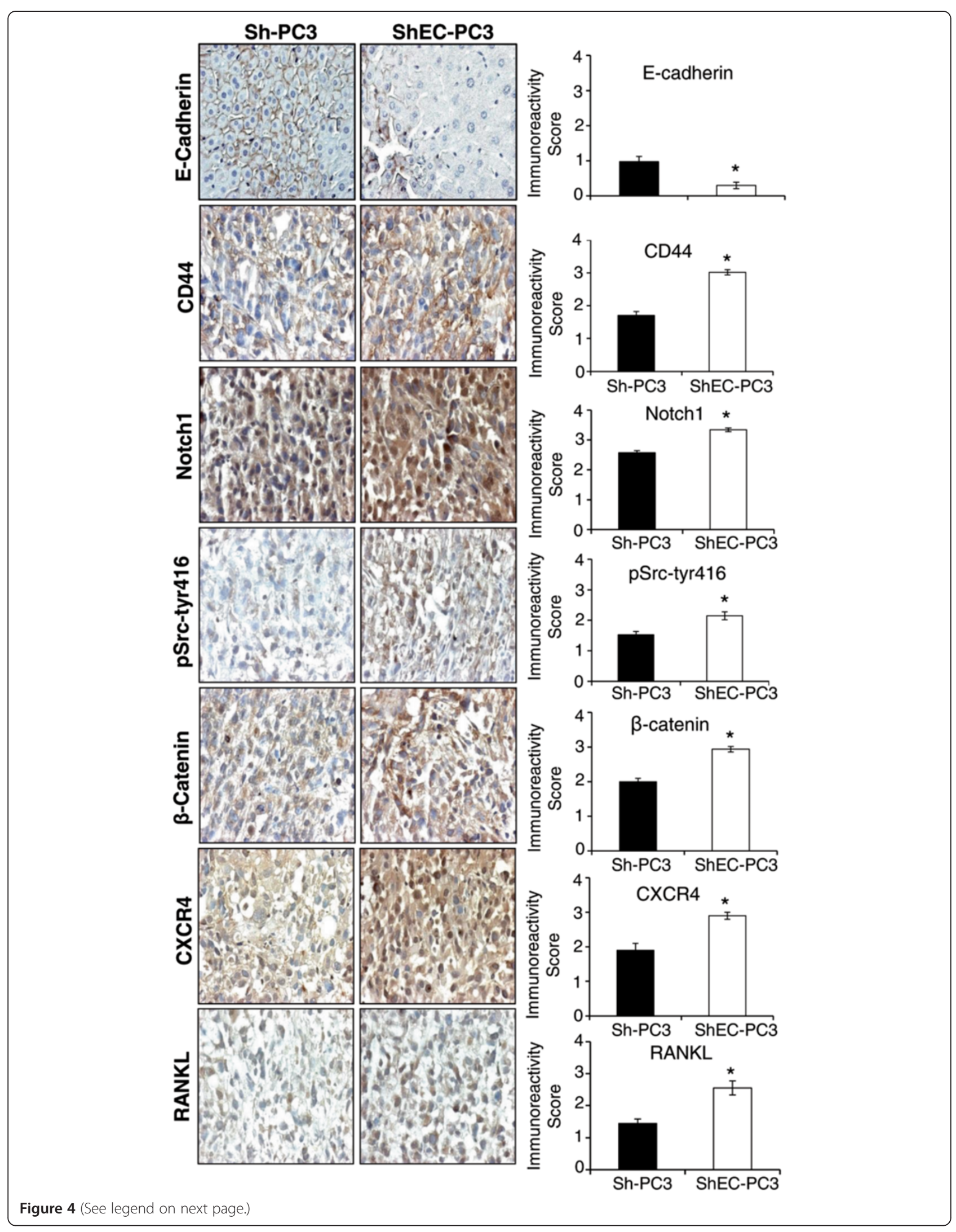


(See figure on previous page.)

Figure 4 Expression of stemness, EMT, and bone metastasis biomarkers in Sh-PC3 and ShEC-PC3 xenograft tissues. Sh-PC3 and ShEC-PC3 xenograft tissues were analyzed for the expression of E-cadherin, CD44, Notch1, pSrc-tyr416, $\beta$-catenin, CXCR4 and RANKL by IHC as detailed in the methods. Immunoreactivity was analyzed in 5 random areas for each tumor tissue and was scored as $0+$ (no staining), 1+ (weak staining), $2+$ (moderate staining), 3+ (strong staining), 4+ (very strong staining). IHC scores (as mean \pm SEM) are shown as bar diagram of 5-10 samples.

observed in cytoplasmic fraction of all the cell lines tested with least expression in DU-145 cells (Figure 7A). On the contrary, nuclear SNAI1 expression was highest in DU-145 cells followed by WPE1-NB14, WPE1-NA22 and RWPE-1 cells (Figure 7A). Immunoblotting results for E-cadherin and SNAI1 expression in these 4 cell lines were further confirmed by confocal microscopy (Figure 7B). Immunofluorescence analysis also showed that RWPE-1 cells have polygonal morphology with intact cell-cell contact that was progressively lost in WPE1-NA22,

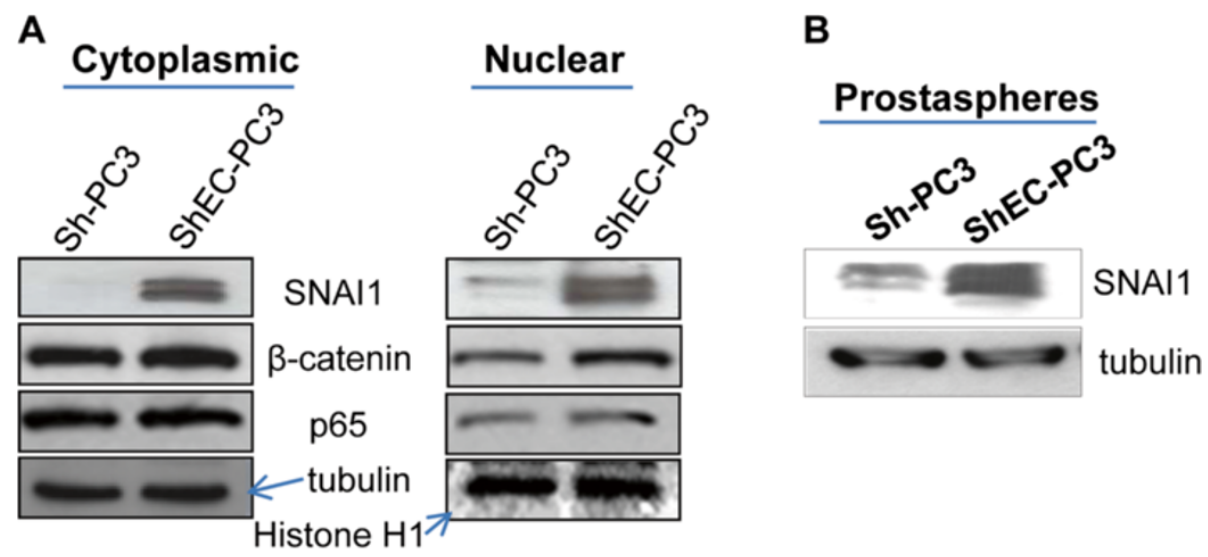

C
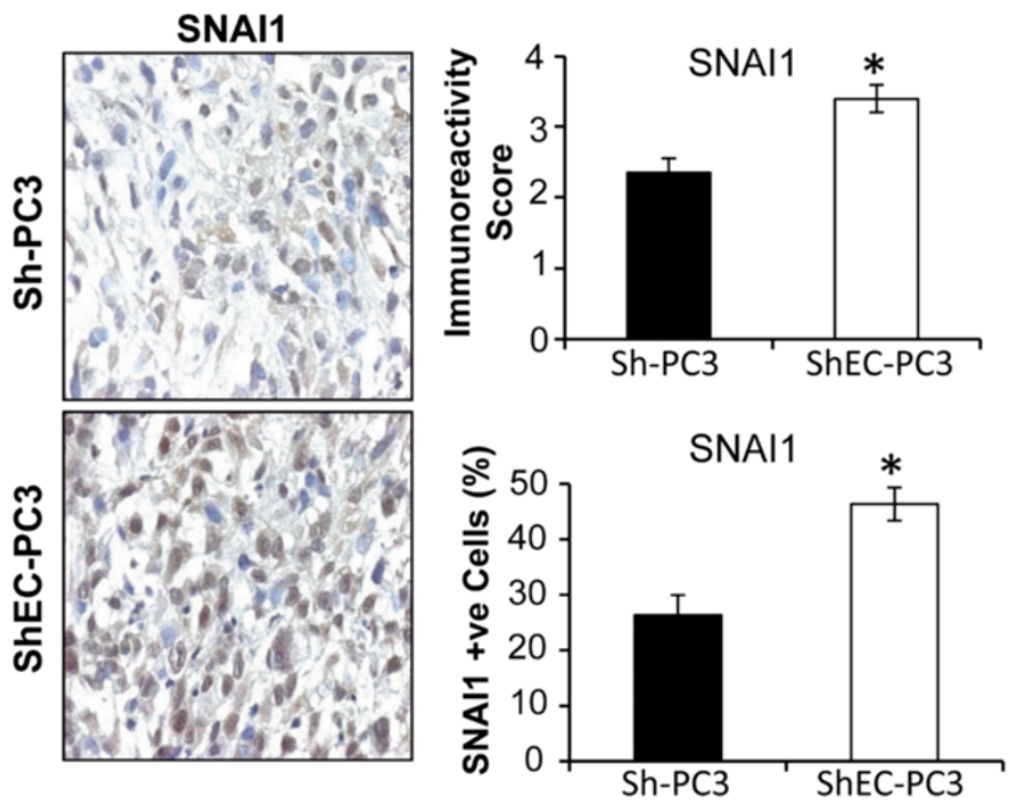

Figure 5 Effect of E-cadherin knock-down on the expression of SNAI1 and other transcriptional factors. (A) Sh-PC3 and ShEC-PC3 cells were collected at similar confluency and nuclear/cytoplasmic fractions were prepared and analyzed for SNAI1, $\beta$-catenin, and p65 expression by Western blotting. Tubulin and histone $\mathrm{H} 1$ were used as loading control for cytoplasmic and nuclear fractions respectively. (B) Sh-PC3 and ShEC-PC3 prostaspheres were collected following centrifugation and cell lysates were prepared and analyzed for SNAl1 expression by Western blotting. (C) Sh-PC3 and ShEC-PC3 xenograft tissues were analyzed for the expression of SNAl1 by IHC. Immunoreactivity score was analyzed in 5 random areas for each tumor tissue and was scored as $0+$ (no staining), 1+ (weak staining), 2+ (moderate staining), 3+ (strong staining), 4+ (very strong staining). Percentage of SNAl1 positive cells was calculated by counting the number of positive stained cells (brown stained) and the total number of cells at five arbitrarily selected fields from each tumor at 400x magnification. The data shown in the bar diagrams is the mean \pm SEM of 7-10 samples. *, $p \leq 0.001$. 


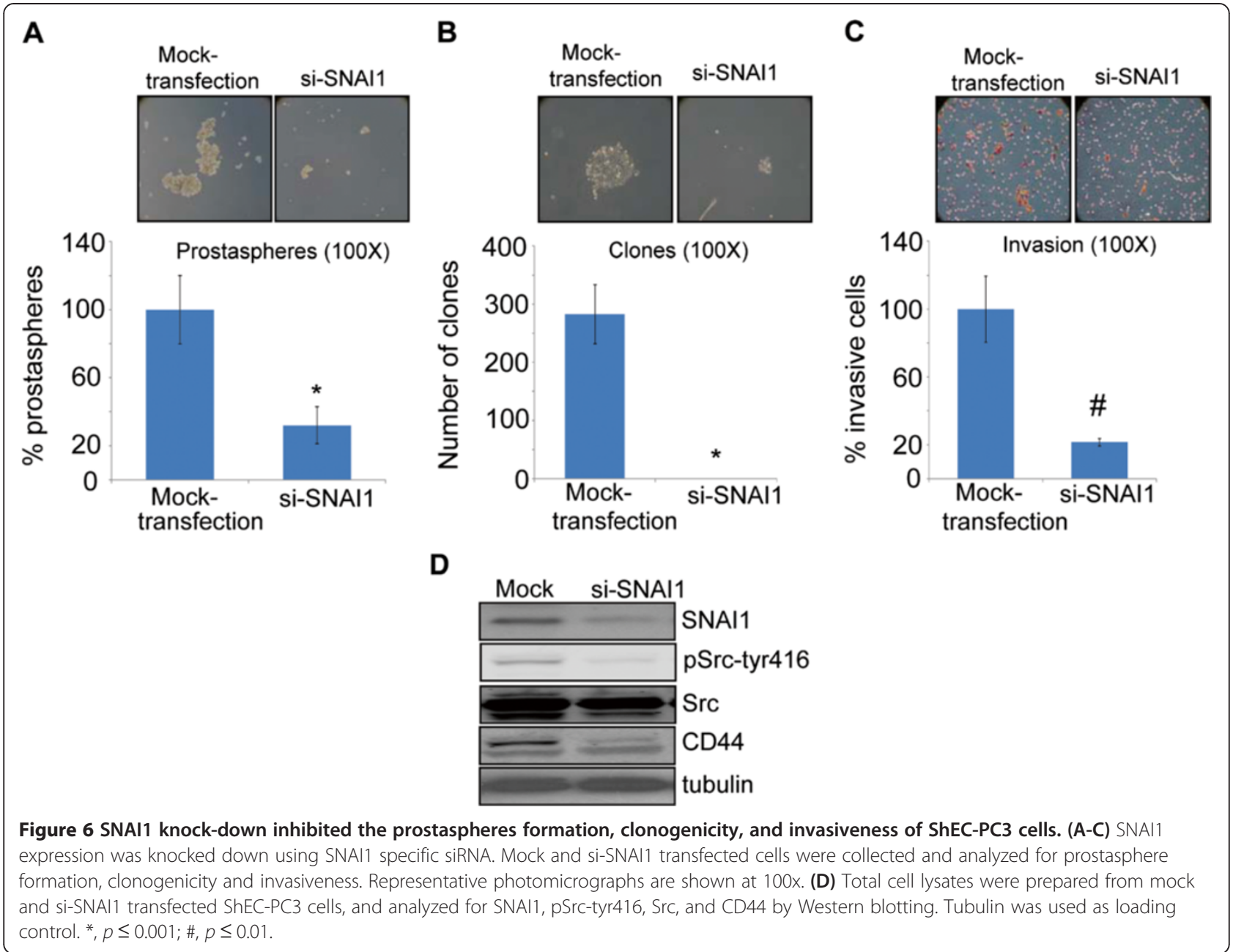

WPE1-NB14 and DU-145 cells together with a decrease in E-cadherin and an increase in SNAI1 expression (Figure 7B). Next, we compared the prostasphere formation in these 4 cell lines. As shown in Figure 7C, RWPE-1 and WPE1NA22 cells did not form prostaspheres or formed relatively smaller sized prostaspheres, while WPE1-NB14 and DU-145 cells formed larger number and bigger sized prostaspheres. Overall, DU-145 cells (with lowest E-cadherin and highest SNAI1 expression) formed highest number and biggest sized prostaspheres among all the four cell lines studied here (Figure 7C).

\section{Discussion}

Lately, targeted therapies are being exploited to develop personalized medicines based upon the specific mutations and molecular alterations in cancer cells. Accordingly, the identification and functional characterization of important early molecular alterations, which are involved in the growth and progression of prostate cancer (PCA), remain vital towards devising novel targeted preventive and therapeutic strategies. In PCA patients, the main cause of death is the metastatic spread of the disease; however, it remains extremely difficult to predict indolent versus aggressive tumor when diagnosed at an early stage. Now, EMT has been suggested to be required by stationery cancer cells to acquire phenotypic and functional characteristics for metastasis. Therefore, EMT biomarkers have been extensively examined to predict disease outcome [20-23,26]. In this regard, E-cadherin loss or reduced expression at the membrane of neoplastic cells has often been associated with worsening histological grade and clinical stage along with poor prognosis in a variety of cancers including prostate, gastric, and breast $[18,19,23,40,41]$. However, heterogeneity in E-cadherin expression has been observed in PCA metastatic tissues with few studies reporting reduced E-cadherin expression while others reporting normal or higher E-cadherin expression in metastatic tissues compared to primary tumor tissues [21,22,42-45]. Putzke et al. even reported difference in the E-cadherin expression dependent upon the metastatic organ site with significantly higher E-cadherin expression observed in bone metastatic tissues compared to soft tissue metastases 


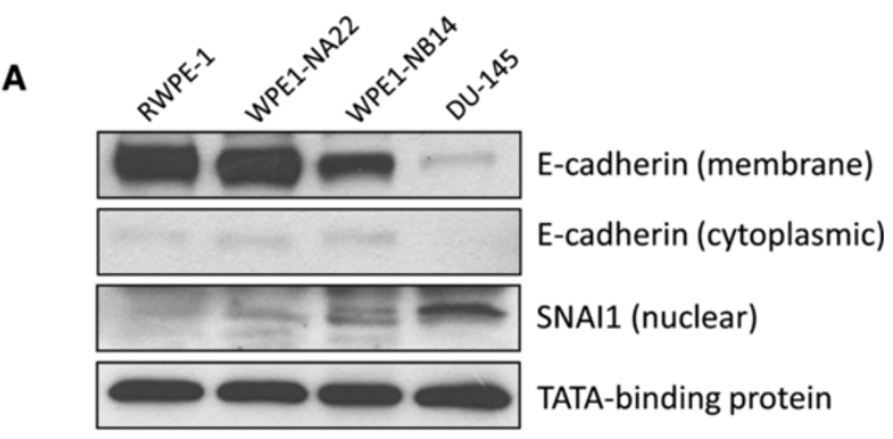

B
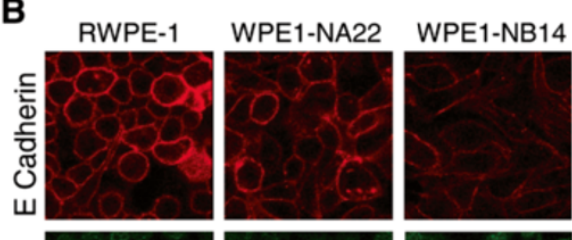

DU-145
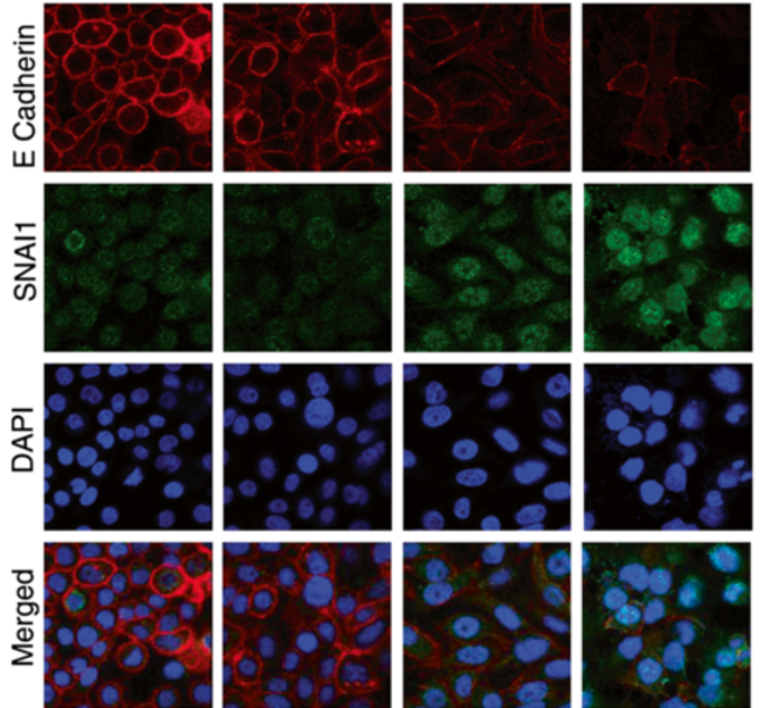

C

RWPE-1 WPE1-NA22 WPE1-NB14
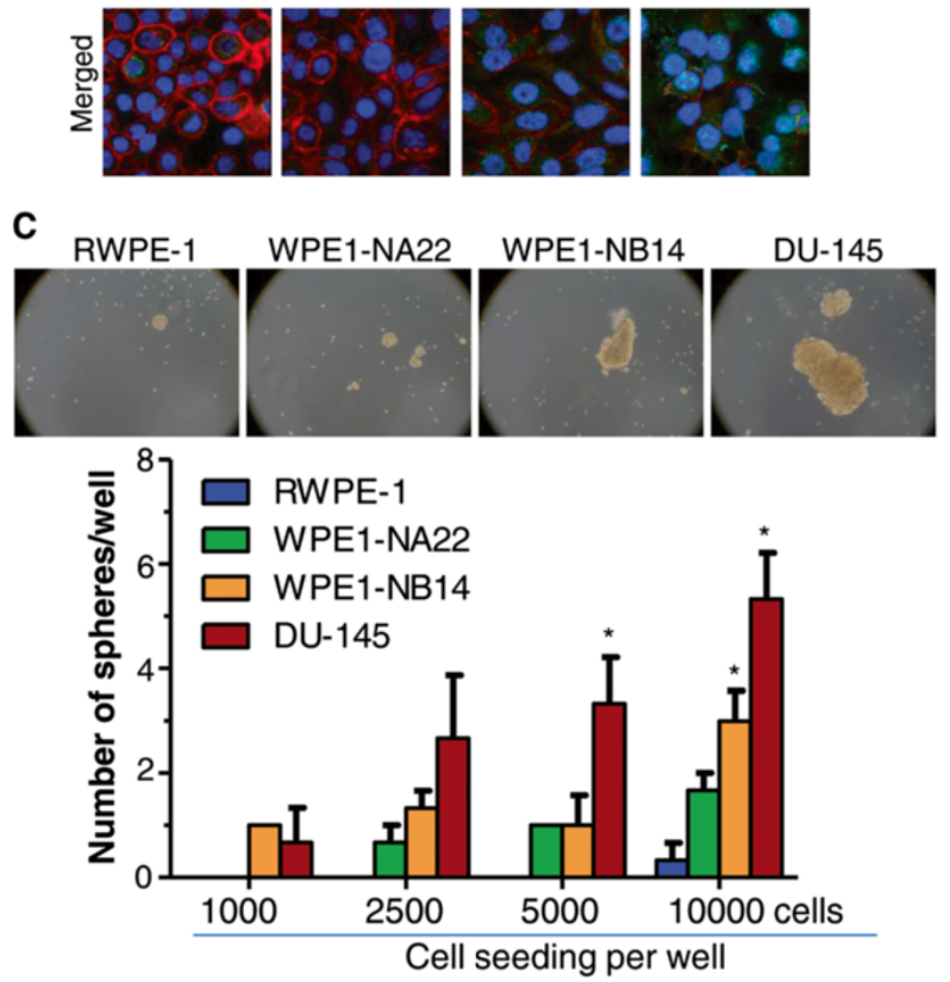

Figure 7 (See legend on next page.) 
(See figure on previous page.)

Figure 7 Low E-cadherin is associated with high SNAI1 and prostasphere formation. (A-B) E-cadherin and SNAl1 expression was analyzed in RWPE-1, WPE1-NA22, WPE1-NB14, and DU-145 cells via immunoblotting and confocal microscopy methods. Representative confocal pictures are shown (at 1500x) where Alexa Fluor 555-red is for E-cadherin, Alexa Fluor 488-green is for SNAl1, while DAPI-blue stains nuclei. (C) RWPE-1, WPE1-NA22, WPE1-NB14, and DU-145 cells were plated on 6 well Corning ultra-low attachment plates in DMEM/F-12(Ham) media containing supplements B27 and N2. Prostasphere formation was measured after 8 days. Representative prostasphere pictures are shown at 100x. Data shown is mean \pm SEM of 3 samples. * $p \leq 0.001$ (compared to RWPE-1 prostasphere number).

[41]. The expression of another EMT regulator i.e. SNAI1 has also been correlated with an increased risk of tumor relapse and poor survival in breast cancer patients, and with the progression of colorectal cancer [23,46,47]. Recently, Whiteland et al. [23], using 215 archival PCA patient tissue samples analyzed the expression and subcellular localization of several EMT biomarkers to correlate them with disease outcome. This study revealed that loss of E-cadherin expression at the cellular membrane of PCA cells is significantly associated with increasing Gleason score and clinical stage, and a poor survival. Furthermore, nuclear SNAI1 expression was significantly increased in PCA tissue and was strongly associated with increasing Gleason score and clinical stage but did not demonstrate a significant association with PSA (prostate specific antigen) recurrence or patient survival. Therefore, E-cadherin and SNAI1 are important in the clinical progression of the disease; and in the present study, we demonstrate the role of E-cadherin and SNAI1 in conferring several aggressive characteristics to PCA cells such as higher proliferation rate, clonogenicity, stemness and increased expression of biomarkers for stemness, EMT, and metastasis.

There have been several studies suggesting that EMT not only enhances the motility and invasiveness of cancer cells, but also provide several additional aggressive features such as stemness, therapeutic and anoikis resistance etc. Gupta et al. [13] have shown that E-cadherin downregulation not only induces EMT but also enhances the CSC population in breast cancer cells. In fact, a greater degree of overlapping has been observed in the CSC population as well as invasive or metastatic cells. Balic et al. reported that most of the early disseminated cancer cells detected in the bone marrow of breast cancer patients have a putative CSC phenotype [48]. In another study, Aktas et al. showed that a major proportion of circulating tumor cells in the blood of breast cancer patients has stem cell characteristics [49]. One explanation put forward to describe high-stemness in metastatic cancer cells is that 'stationary CSC' could undergo EMT and give rise to 'metastatic CSC' [50-52]. Another line of experimental evidence suggests that EMT induction in differentiated neoplastic epithelial cells (non-CSC population) not only enhances invasiveness but also their stemness [13,14,51,53,54]. In any case, increased stemness might provide the necessary plasticity to cancer cells required to adapt to varying microenvironments during the arduous metastatic journey and colonization at distant organ sites. Results from the present study also support the argument that 'EMT enhances stemness' as E-cadherin knock-down significantly enhanced the clone and prostasphere formation by PC3 cells. However, Celia-Terrassa et al. have reported that PC3-derived clonal populations enriched for epithelial phenotype exhibit a stronger expression of self-renewal/ pluripotency gene networks and more aggressive attributes [55]. Furthermore, the suppression of epithelial program inhibited the self-renewal/pluripotency gene network of tumor cells, their capacity to grow under attachment-independent conditions, and their tumorigenic and metastatic potentials [55]. This study also suggested the coexistence of heterogeneous populations with epithelial or mesenchymal phenotype interacting and cooperating to impact on the tumor's potency for local invasiveness and distant metastasis. Together, these studies highlight the plasticity in PCA cells where epithelial, mesenchymal, and intermediate or a mix of these states could impart contextual advantages dependent upon cancer stage and/or tumor microenvironment.

SNAI1 is a member of the zinc-finger transcription factor family and is known to repress E-cadherin expression [56]. SNAI1 is located on chromosome 20q13 that exhibits gene amplification in tumor samples from metastatic PCA [57]. Increased SNAI1 expression is considered an early event in the progress of prostate carcinogenesis but is limited to cells with invasive properties [26]. SNAI1 is also reported to enhance RANKL expression, osteoclastogenesis and bone colonization [58]. Furthermore, SNAI1 regulates CSC activity and tumorigenicity in breast and colorectal carcinoma cells $[14,28]$; and CRC patients with abundant SNAI1 expression exhibit high metastasis [28]. Baygi et al. reported that SNAI1 knock-down significantly reduced the viability of human PCA cells and prevented their reattachment potential through modulating the expression of Integrins [24]. This study also suggested that SNAI1 primarily acts as a survival factor and inhibitor of cellular senescence. SNAI1 overexpression in ARCaP PCA cells induced EMT through ROS (reactive oxygen species) generation, increase in the expression of inflammatory chemokine CCL5 and ERK activation [59]; and SNAI1 knock-down in C4-2 and ARCaP cells overexpressing SNAI1 significantly compromised their migration potential [60]. Neal et al. have reported that higher SNAI1 expression could promote migration and invasion in PCA cells 
through negatively regulating the expression of protease inhibitor Maspin [61]. SNAI1 has also been reported to increase the expression of mesenchymal markers Vimentin and Fibronectin as well as other proteins involved in cancer invasion such as metalloproteinases 2 and 9 , and various transcription factors such as ZEB-1 and LEF-1 $[62,63]$. SNAI1 expression is inversely correlated with RKIP (Raf kinase inhibitor protein), a metastatic suppressor protein that inhibits cell survival, proliferation and invasiveness through targeting Raf-1/MEK/ERK and NF- $\mathrm{kB}$ signaling pathways $[63,64]$. In the present study, we observed that knock-down of E-cadherin expression in PC3 cells resulted in a strong increase in SNAI1 expression both in cell culture (cells and prostaspheres) as well as xenograft tissues; and that SNAI1 inhibition reduced the stemness, clonogenicity and invasiveness of ShEC-PC3 cells. It is possible that SNAI1 inhibition reduces the survival of ShEC-PC3 cells potentially by inducing senescence and/or apoptosis involving down-regulation of Integrins, Vimentin or other EMT regulators, decrease in ROS level, and increase in Maspin and/or RKIP as reported in above studies. Our results also suggested that SNAI1 inhibition could reduce the stemness of ShEC-PC3 cells through a decrease in CD44 expression (as shown in Figure 6D). Also, SNAI1 knock-down in ShEC-PC3 cells could reduce the invasiveness through inhibiting Src phosphorylation (Figure 6D). Therefore, there could be several molecular mechanisms possible for the inhibitory effect of SNAI1 knock-down on the stemness and invasiveness of ShEC-PC3 cells, and these need to be investigated further in future.

It is now well established that SNAI1 transcriptionally down-regulates E-cadherin expression; however, here we report an interesting finding that SNAI1 expression is increased following E-cadherin knock-down in PC3 cells. Therefore, the loss of E-cadherin and SNAI1 up-regulation could be inter-related during prostate carcinogenesis, where SNAI1 increase could repress E-cadherin expression, and vice versa. Earlier studies have shown that GSK-3 $\beta$ (glycogen synthase kinase-3 beta) phosphorylates SNAI1 and promotes its export from the nucleus and subsequent degradation by the proteasome in the cytosol $[19,65]$. Conversely, PAK1 (p21-activated kinase) could phosphorylate SNAI1 to promote its nuclear localization and activity as a transcriptional factor $[19,66]$. Du et al. reported that protein kinase D1 (PKD1) could also phosphorylate SNAI1 at Ser11, triggering its nuclear export via 14-3-30 binding [19]. Wu et al. have shown that NF-kB also plays an important role in the stabilization of SNAI1 $[19,67]$. One possibility for the observed increase in SNAI1 expression with E-cadherin knock-down could be increased nuclear $\beta$-catenin which could enhance SNAI1 expression. Similarly, there was a slight increase in nuclear p65 expression with E-cadherin knock-down, which could also enhance SNAI1 expression. Also, E-cadherin knock-down could modify the phosphorylation status of SNAI1 favoring its nuclear localization and stabilization possibly through a decrease in GSK-3 $\beta$ and/or PKD1 or an increase in PAK1 and/or NF- $\kappa B$ activity. Further studies are warranted to clearly define the molecular mechanisms through which E-cadherin loss results in higher SNAI1 expression.

Together, the existing literature as well as results from the present study suggest that it is feasible to prevent metastasis in PCA patients with localized disease through re-activating/increasing E-cadherin expression or through targeting SNAI1 expression in PCA cells by using existing or novel cancer preventive agents [68-70]. For example, earlier we have reported that in TRAMP (transgenic adenocarcinoma of the mouse prostate) mice E-cadherin expression is lost while SNAI1 expression is increased with disease progression from PIN to poorly differentiated adenocarcinoma stages [70]; and the administration of the cancer chemopreventive agent Silibinin, a natural flavonoid from Milk thistle extract, strongly enhanced E-cadherin expression while it decreased SNAI1 expression and prevented PCA metastasis to distant organs [70]. Recently, Harney et al. developed a novel strategy to target SNAI1 expression in cancer cells [71]. They conjugated $\mathrm{Co}(\mathrm{III})$ Schiff base complexes with specific oligonucleotide i.e. Co(III)-Ebox selectively targeting the E-box-binding zinc finger family transcriptional factors resulting in enhanced E-cadherin promoter activity in MCF7 cells [71]. But it should be cautioned that SNAI1 plays an important role during embryonic development and is also considered an important stem cell regulator, therefore SNAI1 inhibitors should be specifically targeted towards cancer cells. Also, SNAI1 inhibition could possibly cause the re-expression of E-cadherin as well as other epithelial markers in metastatic tissues, where higher E-cadherin or epithelial characteristics could favor better survival and proliferation $[41,55]$. This clearly reflects the challenge of understanding and targeting the epithelial plasticity in PCA, as E-cadherin promotion and SNAI1 downregulation could prevent growth and invasiveness in primary tumors; however, could potentially enhance growth at certain metastatic sites.

\section{Conclusions}

Overall, results from the present study suggest that the EMT regulators- E-cadherin and SNAI1 could be used for disease prognosis as well as suitably targeted to prevent PCA metastatic progression.

\section{Methods}

\section{Cells culture and reagents}

Human prostate carcinoma PC3, RWPE-1, WPE1-NA22, WPE1-NB14 and DU-145 cells were obtained from American Type Culture Collection (Manassas, VA). Sh-PC3 and ShEC-PC3 cells were cultured in RPMI1640 medium 
supplemented with $10 \%$ heat inactivated fetal bovine serum (FBS), $100 \mathrm{U} / \mathrm{ml}$ penicillin $\mathrm{G}, 100 \mu \mathrm{g} / \mathrm{ml}$ streptomycin sulfate and puromycin at $37^{\circ} \mathrm{C}$ in a humidified $5 \% \mathrm{CO}_{2}$ incubator. RWPE-1, WPE1-NA22, and WPE1-NB14 cells were cultured in keratinocyte serum-free medium containing $50 \mu \mathrm{g} / \mathrm{ml}$ bovine pituitary extract and $5 \mathrm{ng} / \mathrm{ml}$ epidermal growth factor. DU-145 cells were cultured in RPMI1640 medium supplemented with 10\% heat inactivated FBS, $100 \mathrm{U} / \mathrm{ml}$ penicillin $\mathrm{G}$ and $100 \mu \mathrm{g} / \mathrm{ml}$ streptomycin sulfate. Media and other cell culture materials as well as fluorescently conjugated anti-mouse and antirabbit IgG antibodies were from Invitrogen Corporation (Gaithersburg, MD). Antibodies for $\beta$-catenin, Vimentin, Egr-1 (early growth response-1), CXCR4, uPA (Urokinase plasminogen activator), RANKL (receptor activator of nuclear factor kappa-B ligand), p65, RunX2, Histone H1 and E-cadherin shRNA plasmid were purchased from Santa Cruz Biotechnology (Santa Cruz, CA). Antibodies for E-cadherin, CD44, Integrin $\beta 3$, SNAI1, cleaved Notch1, pSrc-tyr416, total Src, and anti-rabbit peroxidase-conjugated secondary antibody were obtained from Cell Signaling (Beverly, MA). SNAI1, N-cadherin, OB-cadherin and TATA-binding protein (TBP) antibodies were from Abcam (Cambridge, MA). Puromycin, DAPI (4',6-diamidino2 -phenylindole), and $\beta$-actin antibody were from SigmaAldrich (St Louis, MO). ECL detection system and antimouse HRP-conjugated secondary antibody were from GE Healthcare (Buckinghamshire, UK). On-Target plus smart pool SNAI1 siRNA was purchased from Thermo Scientific (Waltham, MA) and HiPerfect transfection reagent was from Qiagen (Valencia, CA). Antibody for $\alpha$-tubulin was from Lab Vision Corporation (Fremont, CA). All other reagents were obtained in their commercially available highest purity grade.

\section{Transfection}

PC3 cells with stable knock-down of E-cadherin (ShEC-PC3 cells) and respective control cells (Sh-PC3 cells) were generated as published earlier [36]. For SNAI1 knock-down, ShEC-PC3 cells $\left(\sim 5 \times 10^{5}\right)$ were plated in $60 \mathrm{~mm}$ dishes for 24 hrs. SNAI1 siRNA and transfection reagents were mixed in $100 \mu \mathrm{l}$ serum free media and added drop-wise over ShEC-PC3 cells. Serum containing media was added $1 \mathrm{hr}$ after transfection. Cells were collected after $48 \mathrm{hrs}$ and knock-down was confirmed by Western blotting. In other studies, cells were also collected and analyzed in clonogenic, prostasphere and invasion assays.

\section{MTT assay}

Sh-PC3 and ShEC-PC3 Cells were plated at a density of 1000 cells/well in 96-well plate under standard culture conditions. At the end of indicated time-point, fresh media containing $20 \mu \mathrm{l}$ of MTT (5 mg/ml stock) was added, and incubated for another $4 \mathrm{~h}$ in a $\mathrm{CO} 2$ incubator. At the end, media was removed and $200 \mu \mathrm{l}$ of DMSO was added to each well. Color intensity was measured by taking absorbance at $540 \mathrm{~nm}$.

\section{Clonogenic assay}

Sh-PC3 and ShEC-PC3 cells $\left(\sim 1 \times 10^{3}\right.$ per well $)$ were plated in 6-well plates. Fresh media was added every $48 \mathrm{~h}$. At the end of the $7^{\text {th }}$ day, cells were washed twice with ice cold PBS, fixed with a mixture of methanol and glacial acetic acid $(3: 1)$ for 10 minutes and then stained with $1 \%$ crystal violet in methanol for 15 minutes followed by washing with deionized water. Colonies with more than 50 cells were scored and counted under the microscope. Photomicrographs were taken using Canon Power Shot digital camera.

\section{Matrigel invasion assay}

Invasion assay was performed using matrigel invasion chambers from BD Biosciences as per vendor's protocol. Briefly, the bottom chambers were filled with RPMI1640 media with $10 \%$ FBS and the top chambers (inserts) were seeded with 50,000 cells (mock or SNAI1 siRNA transfected) per well in RPMI1640 media (with 0.5\% FBS). Top chambers have a thin layer of matrigel, and PCA cells invaded through the matrigel layer and 8 micron membrane pores. After $22 \mathrm{~h}$ of incubation under standard culture conditions, cells on the top matrigel surface (non-invasive cells) were scraped with a cotton swab and the cells spreading on the bottom sides of the membrane (invasive cells) were fixed, stained, and mounted. Images were captured using Cannon Power Shot A640 camera on Zeiss inverted microscope and total number of invasive cells was counted and percentage of cell invasion was calculated.

\section{Prostasphere assay}

Sh-PC3, ShEC-PC3, RWPE-1, WPE1-NA22, WPE1-NB14 and DU-145 cells (1000, 2500, 5000, or 10000 cells) were plated in 6 well Corning ultra-low attachment plates in DMEM/F-12(Ham) media containing supplements B27 and N2 (from Invitrogen). Cell culture was monitored daily to assess that sphere originated from single cell; however cells or spheres aggregation cannot be completely ruled out. In each case, number of prostaspheres (with average diameter more than $75 \mu \mathrm{m}$ ) formed after 5-8 days was counted under a microscope. Prostasphere images were captured using Cannon Power Shot A640 camera on Zeiss inverted microscope.

\section{Immunoblotting}

Total or nuclear/cytoplasmic lysates were prepared following published protocol [72,73] and sub-cellular fractionations were prepared as per vendor's protocol (ThermoFisher Scientific, Rockford, IL). Approximately, 50-70 $\mu \mathrm{g}$ of protein 
lysate per sample was denatured in 2x sample buffer and subjected to sodium dodecyl sulfate-polyacrylamide gel electrophoresis (SDS-PAGE) on 6 or 12\% Tris-glycine gel (as required based upon the protein molecular weight). The separated proteins were transferred on to nitrocellulose membrane followed by blocking with $5 \%$ non-fat milk powder (w/v) in Tris-buffered saline $(10 \mathrm{mM}$ Tris- $\mathrm{HCl}$, $\mathrm{pH} 7.5,100 \mathrm{mM} \mathrm{NaCl}, 0.1 \%$ Tween 20) for $1 \mathrm{~h}$ at room temperature. Membranes were probed for the protein levels of desired molecules using specific primary antibodies followed by the appropriate peroxidase-conjugated secondary antibody and visualized by ECL detection system. To ensure equal protein loading, each membrane was stripped and re-probed with appropriate loading control. The autoradiograms/bands were scanned with Adobe Photoshop 6.0 (Adobe Systems, San Jose, CA). In each case, blots were subjected to multiple exposures on the film to make sure that the band density is in the linear range.

\section{Xenograft study and Immunohistochemistry (IHC)}

Athymic $(n u / n u)$ male nude mice were housed at the University of Colorado Denver (UCD) animal care facility. Protocols were approved by UCD Institutional Animal Care and Use Committee. Approximately, 1 million Sh-PC3 or ShEC-PC3 cells were suspended in $0.05 \mathrm{ml}$ of serum-free medium (RPMI1640), mixed with $0.05 \mathrm{ml}$ of matrigel and were s.c. injected in each flank of male athymic nude mouse (NCI-Frederick, Bethesda, MD) ( $\mathrm{n}=5$ with total 10 xenografts for each group) to initiate tumor growth. Once the tumor xenograft started growing, their sizes were measured (every $4^{\text {th }}$ day) in two dimensions using a digital caliper. The tumor volume was calculated by the formula: $0.5236 \mathrm{~L}_{1}\left(\mathrm{~L}_{2}\right)^{2}$, where $\mathrm{L}_{1}$ is the long diameter and $\mathrm{L}_{2}$ is short diameter. At the end, each tumor was carefully dissected and processed for IHC following published methods [74]. Briefly, sections were incubated with desired primary antibody followed by incubation with a specific biotinylated secondary antibody, followed by conjugated HRP streptavidin, DAB working solution, and finally counterstained with hematoxylin. Stained tumor sections were analyzed by Zeiss Axioscope 2 microscope and images were captured by the AxioCam $\mathrm{MrC5}$ camera at 400x magnifications.

\section{Confocal imaging}

RWPE-1, WPE1-NA22, WPE1-NB14 and DU-145 cells were grown on cover slips and incubated in media for $24 \mathrm{hrs}$. Cells were then fixed in $3.7 \%$ formaldehyde, washed with PBS, permeabilized with $0.2 \%$ Triton X-100 overnight at $4{ }^{\circ} \mathrm{C}$ along with primary antibodies for Ecadherin and SNAI1. Cells were then washed with PBS and incubated with secondary antibodies and DAPI for $60 \mathrm{~min}$. Cell images were captured at 1500× magnification on a Nikon inverted confocal microscope using 561/488/ $405 \mathrm{~nm}$ laser wavelengths to detect E-cadherin (Red), SNAI1 (Green) and DAPI (Blue) emissions, respectively.

\section{Statistical analysis}

Statistical analysis was performed using SigmaStat 2.03 software (Jandel Scientific, San Rafael, CA). Data was analyzed using one way ANOVA and a statistically significant difference was considered at $p<0.05$.

\section{Competing interests}

The authors declare that they have no competing interests

\section{Authors' contributions}

GD contributed to the conception and design of the study, coordinated the research, performed the xenograft, Western blotting, prostasphere and knock-down experiments, and wrote the manuscript. AKJ performed the $\mathrm{IHC}$. AR and HT performed the confocal studies, Western blotting for several proteins and proof read the manuscript. KCV and SCG carried out the MTT and clonogenic assays. CA contributed in the design of several experiments, Western blotting and proof read the manuscript. RA conceived the study, elaborated its design, coordinated the research, and critically revised the manuscript. All the authors have read and approved the final manuscript.

\section{Acknowledgements}

This work was supported by NCI RO1 grant CA102514 (to RA) and Institutional Research Grant 57-001-53 from the American Cancer Society (to GD). Authors also acknowledge the CCSG P30CA046934 grant for supporting the UCD Shared Resources used in this study.

\section{Author details}

${ }^{1}$ Department of Pharmaceutical Sciences, Skaggs School of Pharmacy and Pharmaceutical Sciences, San Diego, USA. ${ }^{2}$ University of Colorado Cancer Center, University of Colorado Denver, Aurora, Colorado, USA. ${ }^{3}$ Department of Molecular Biology and Biotechnology, Tezpur University, Tezpur, India.

Received: 25 September 2013 Accepted: 21 February 2014 Published: 24 February 2014

\section{References}

1. Siegel R, Naishadham D, Jemal A: Cancer statistics, 2013. CA Cancer J Clin 2013, 63:11-30

2. Kingsley LA, Fournier PG, Chirgwin JM, Guise TA: Molecular biology of bone metastasis. Mol Cancer Ther 2007, 6:2609-2617.

3. Tantivejkul K, Kalikin LM, Pienta KJ: Dynamic process of prostate cancer metastasis to bone. J Cell Biochem 2004, 91:706-717.

4. Hadaschik BA, Gleave ME: Therapeutic options for hormone-refractory prostate cancer in 2007. Urol Oncol 2007, 25:413-419.

5. Ye XC, Choueiri M, Tu SM, Lin SH: Biology and clinical management of prostate cancer bone metastasis. Front Biosci 2007, 12:3273-3286.

6. Saad F, Markus R, Goessl C: Targeting the receptor activator of nuclear factor-kappaB (RANK) ligand in prostate cancer bone metastases. BJU Int 2008, 101:1071-1075.

7. Msaouel P, Pissimissis N, Halapas A, Koutsilieris M: Mechanisms of bone metastasis in prostate cancer: clinical implications. Best Pract Res Clin Endocrinol Metab 2008, 22:341-355.

8. Buijs JT, van der Pluijm G: Osteotropic cancers: from primary tumor to bone. Cancer Lett 2009, 273:177-193.

9. Deep G, Agarwal R: Antimetastatic efficacy of silibinin: molecular mechanisms and therapeutic potential against cancer. Cancer Metastasis Rev 2010, 29:447-463.

10. Guarino M, Rubino B, Ballabio G: The role of epithelial-mesenchymal transition in cancer pathology. Pathology 2007, 39:305-318.

11. Christiansen JJ, Rajasekaran AK: Reassessing epithelial to mesenchymal transition as a prerequisite for carcinoma invasion and metastasis. Cancer Res 2006, 66:8319-8326.

12. Drasin DJ, Robin TP, Ford HL: Breast cancer epithelial-to-mesenchymal transition: examining the functional consequences of plasticity. Breast Cancer Res 2011, 13:226. 
13. Gupta PB, Onder TT, Jiang G, Tao K, Kuperwasser C, Weinberg RA, Lander ES: Identification of selective inhibitors of cancer stem cells by high-throughput screening. Cell 2009, 138:645-659.

14. Mani SA, Guo W, Liao MJ, Eaton EN, Ayyanan A, Zhou AY, Brooks M, Reinhard F, Zhang CC, Shipitsin M, Campbell LL, Polyak K, Brisken C, Yang J, Weinberg RA: The epithelial-mesenchymal transition generates cells with properties of stem cells. Cell 2008, 133:704-715.

15. Polyak K, Weinberg RA: Transitions between epithelial and mesenchymal states: acquisition of malignant and stem cell traits. Nat Rev Cancer 2009, 9:265-273.

16. Baranwal S, Alahari SK: Molecular mechanisms controlling E-cadherin expression in breast cancer. Biochem Biophys Res Commun 2009, 384:6-11.

17. Jiang YG, Luo Y, He DL, Li X, Zhang LL, Peng T, Li MC, Lin YH: Role of Wnt/beta-catenin signaling pathway in epithelial-mesenchymal transition of human prostate cancer induced by hypoxia-inducible factor-1alpha. Int J Urol 2007, 14:1034-1039.

18. Peinado H, Olmeda D, Cano A: Snail, Zeb and bHLH factors in tumour progression: an alliance against the epithelial phenotype? Nat Rev Cancer 2007, 7:415-428.

19. Du C, Zhang C, Hassan S, Biswas MH, Balaji KC: Protein kinase D1 suppresses epithelial-to-mesenchymal transition through phosphorylation of snail. Cancer Res 2010, 70:7810-7819.

20. Umbas R, Isaacs WB, Bringuier PP, Schaafsma HE, Karthaus HF, Oosterh of GO, Debruyne FM, Schalken JA: Decreased E-cadherin expression is associated with poor prognosis in patients with prostate cancer. Cancer Res 1994, 54:3929-3933.

21. Umbas R, Schalken JA, Aalders TW, Carter BS, Karthaus HF, Schaafsma HE, Debruyne FM, Isaacs WB: Expression of the cellular adhesion molecule $\mathrm{E}$-cadherin is reduced or absent in high-grade prostate cancer. Cancer Res 1992, 52:5104-5109.

22. Cheng L, Nagabhushan M, Pretlow TP, Amini SB, Pretlow TG: Expression of E-cadherin in primary and metastatic prostate cancer. Am J Pathol 1996, 148:1375-1380.

23. Whiteland H, Spencer-Harty S, Thomas DH, Davies C, Morgan C, Kynaston H, Bose P, Fenn N, Lewis P, Bodger O, Jenkins S, Doak SH: Putative prognostic epithelial-to- mesenchymal transition biomarkers for aggressive prostate cancer. Exp Mol Pathol 2013, 95:220-226.

24. Emadi Baygi M, Soheili ZS, Schmitz I, Sameie S, Schulz WA: Snail regulates cell survival and inhibits cellular senescence in human metastatic prostate cancer cell lines. Cell Biol Toxicol 2010, 26:553-567.

25. McKeithen D, Graham T, Chung LW, Odero-Marah V: Snail transcription factor regulates neuroendocrine differentiation in LNCaP prostate cancer cells. Prostate 2010, 70:982-992

26. Heeboll S, Borre M, Ottosen PD, Dyrskjot L, Orntoft TF, Torring N: Snail1 is over-expressed in prostate cancer. APMIS 2009, 117:196-204

27. Mak P, Leav I, Pursell B, Bae D, Yang X, Taglienti CA, Gouvin LM, Sharma VM, Mercurio AM: ERbeta impedes prostate cancer EMT by destabilizing HIF-1alpha and inhibiting VEGF-mediated snail nuclear localization: implications for Gleason grading. Cancer Cell 2010, 17:319-332.

28. Hwang WL, Yang MH, Tsai ML, Lan HY, Su SH, Chang SC, Teng HW, Yang SH, Lan YT, Chiou SH, Wang HW: SNAIL regulates interleukin-8 expression, stem cell-like activity, and tumorigenicity of human colorectal carcinoma cells. Gastroenterology 2011, 141:279-291. 291 e271-275.

29. Hurt EM, Kawasaki BT, Klarmann GJ, Thomas SB, Farrar WL: CD44+ CD24(-) prostate cells are early cancer progenitor/stem cells that provide a model for patients with poor prognosis. Br J Cancer 2008, 98:756-765.

30. Bisson I, Prowse DM: WNT signaling regulates self-renewal and differentiation of prostate cancer cells with stem cell characteristics. Cell Res 2009, 19:683-697.

31. Guzman-Ramirez N, Voller M, Wetterwald A, Germann M, Cross NA, Rentsch CA, Schalken J, Thalmann GN, Cecchini MG: In vitro propagation and characterization of neoplastic stem/progenitor-like cells from human prostate cancer tissue. Prostate 2009, 69:1683-1693.

32. Klarmann GJ, Hurt EM, Mathews LA, Zhang X, Duhagon MA, Mistree T, Thomas SB, Farrar WL: Invasive prostate cancer cells are tumor initiating cells that have a stem cell-like genomic signature. Clin Exp Metastasis 2009, 26:433-446.

33. Kawasaki BT, Hurt EM, Kalathur M, Duhagon MA, Milner JA, Kim YS, Farrar $W L$ : Effects of the sesquiterpene lactone parthenolide on prostate tumor-initiating cells: an integrated molecular profiling approach. Prostate 2009, 69:827-837.
34. Patrawala L, Calhoun T, Schneider-Broussard R, Li H, Bhatia B, Tang S, Reilly JG, Chandra D, Zhou J, Claypool K, Coghlan L, Tang DG: Highly purified CD44+ prostate cancer cells from xenograft human tumors are enriched in tumorigenic and metastatic progenitor cells. Oncogene 2006, 25:1696-1708.

35. Handorean AM, Yang K, Robbins EW, Flaig TW, Iczkowski KA: Silibinin suppresses CD44 expression in prostate cancer cells. Am J Trans/ Res 2009, 1:80-86.

36. Deep G, Gangar SC, Agarwal C, Agarwal R: Role of E-cadherin in antimigratory and antiinvasive efficacy of silibinin in prostate cancer cells. Cancer Prev Res (Phila) 2011, 4:1222-1232.

37. Saad F, Lipton A: SRC kinase inhibition: targeting bone metastases and tumor growth in prostate and breast cancer. Cancer Treat Rev 2010, 36:177-184.

38. Eaton $\mathrm{CL}$, Colombel M, van der Pluijm G, Cecchini M, Wetterwald A, Lippitt J, Rehman I, Hamdy F, Thalman G: Evaluation of the frequency of putative prostate cancer stem cells in primary and metastatic prostate cancer. Prostate 2010, 70:875-882.

39. Webber MM, Quader ST, Kleinman HK, Bello-DeOcampo D, Storto PD, Bice G, DeMendonca-Calaca W, Williams DE: Human cell lines as an in vitro/in vivo model for prostate carcinogenesis and progression. Prostate 2001, 47:1-13.

40. van Roy F, Berx G: The cell-cell adhesion molecule E-cadherin. Cell Mol Life Sci 2008, 65:3756-3788

41. Putzke AP, Ventura AP, Bailey AM, Akture C, Opoku-Ansah J, Celiktas M, Hwang MS, Darling DS, Coleman IM, Nelson PS, Nguyen HM, Corey E, Tewari M, Morrissey C, Vessella RL, Knudsen BS: Metastatic progression of prostate cancer and e-cadherin regulation by zeb1 and SRC family kinases. Am J Pathol 2011, 179:400-410.

42. Saha B, Arase A, Imam SS, Tsao-Wei D, Naritoku WY, Groshen S, Jones LW, Imam SA: Overexpression of E-cadherin and beta-catenin proteins in metastatic prostate cancer cells in bone. Prostate 2008, 68:78-84.

43. Pontes J Jr, Srougi M, Borra PM, Dall' Oglio MF, Ribeiro-Filho LA, Leite KR: Ecadherin and beta-catenin loss of expression related to bone metastasis in prostate cancer. Appl Immunohistochem Mol Morphol 2010, 18:179-184.

44. Rubin MA, Mucci NR, Figurski J, Fecko A, Pienta KJ, Day ML: E-cadherin expression in prostate cancer: a broad survey using high-density tissue microarray technology. Hum Pathol 2001, 32:690-697.

45. De Marzo AM, Knudsen B, Chan-Tack K, Epstein Jl: E-cadherin expression as a marker of tumor aggressiveness in routinely processed radical prostatectomy specimens. Urology 1999, 53:707-713.

46. Fan XJ, Wan XB, Yang ZL, Fu XH, Huang Y, Chen DK, Song SX, Liu Q, Xiao HY, Wang L, Wang JP: Snail promotes lymph node metastasis and Twist enhances tumor deposit formation through epithelial-mesenchymal transition in colorectal cancer. Hum Pathol 2013, 44:173-180.

47. Moody SE, Perez D, Pan TC, Sarkisian CJ, Portocarrero CP, Sterner CJ, Notorfrancesco KL, Cardiff RD, Chodosh LA: The transcriptional repressor Snail promotes mammary tumor recurrence. Cancer Cell 2005, 8:197-209.

48. Balic M, Lin H, Young L, Hawes D, Giuliano A, McNamara G, Datar RH, Cote $\mathrm{RJ}$ : Most early disseminated cancer cells detected in bone marrow of breast cancer patients have a putative breast cancer stem cell phenotype. Clin Cancer Res 2006, 12:5615-5621.

49. Aktas B, Tewes M, Fehm T, Hauch S, Kimmig R, Kasimir-Bauer S: Stem cell and epithelial-mesenchymal transition markers are frequently overexpressed in circulating tumor cells of metastatic breast cancer patients. Breast Cancer Res 2009, 11:R46.

50. Brabletz T, Jung A, Spaderna S, Hlubek F, Kirchner T: Opinion: migrating cancer stem cells - an integrated concept of malignant tumour progression. Nat Rev Cancer 2005, 5:744-749.

51. Gupta PB, Chaffer CL, Weinberg RA: Cancer stem cells: mirage or reality? Nat Med 2009, 15:1010-1012

52. Li H, Tang DG: Prostate cancer stem cells and their potential roles in metastasis. J Surg Oncol 2011, 103:558-562.

53. van der Pluijm G: Epithelial plasticity, cancer stem cells and bone metastasis formation. Bone 2011, 48:37-43.

54. Morel AP, Lievre M, Thomas C, Hinkal G, Ansieau S, Puisieux A: Generation of breast cancer stem cells through epithelial-mesenchymal transition. PLoS One 2008, 3:e2888.

55. Celia-Terrassa T, Meca-Cortes O, Mateo F, de Paz AM, Rubio N, Arnal-Estape A, Ell BJ, Bermudo R, Diaz A, Guerra-Rebollo M, Lozano JJ, Estaras C, Ulloa C, Alvarez-Simon D, Mila J, Vilella R, Paciucci R, Martinez-Balbas M, de Herreros AG, Gomis RR, Kang Y, Blanco J, Fernandez PL, Thomson TM: Epithelial-mesenchymal transition can suppress major attributes of human epithelial tumor-initiating cells. J Clin Invest 2012, 122:1849-1868. 
56. Foubert E, De Craene B, Berx G: Key signalling nodes in mammary gland development and cancer. The Snail1-Twist1 conspiracy in malignant breast cancer progression. Breast Cancer Res 2010, 12:206.

57. Dhanasekaran SM, Barrette TR, Ghosh D, Shah R, Varambally S, Kurachi K Pienta KJ, Rubin MA, Chinnaiyan AM: Delineation of prognostic biomarkers in prostate cancer. Nature 2001, 412:822-826.

58. Odero-Marah VA, Wang R, Chu G, Zayzafoon M, Xu J, Shi C, Marshall FF, Zhau HE, Chung LW: Receptor activator of NF-kappaB Ligand (RANKL) expression is associated with epithelial to mesenchymal transition in human prostate cancer cells. Cell Res 2008, 18:858-870.

59. Barnett P, Arnold RS, Mezencev R, Chung LW, Zayzafoon M, Odero-Marah V: Snail-mediated regulation of reactive oxygen species in ARCaP human prostate cancer cells. Biochem Biophys Res Commun 2011, 404:34-39.

60. Neal CL, McKeithen D, Odero-Marah VA: Snail negatively regulates cell adhesion to extracellular matrix and integrin expression via the MAPK pathway in prostate cancer cells. Cell Adh Migr 2011, 5:249-257.

61. Neal CL, Henderson V, Smith BN, McKeithen D, Graham T, Vo BT, Odero-Marah VA: Snail transcription factor negatively regulates maspin tumor suppressor in human prostate cancer cells. BMC Cancer 2012, 12:336.

62. Smith BN, Odero-Marah VA: The role of Snail in prostate cancer. Cell Adh Migr 2012, 6:433-441.

63. Baritaki S, Chapman A, Yeung K, Spandidos DA, Palladino M, Bonavida B: Inhibition of epithelial to mesenchymal transition in metastatic prostate cancer cells by the novel proteasome inhibitor, NPI-0052: pivotal roles of Snail repression and RKIP induction. Oncogene 2009, 28:3573-3585.

64. Beach S, Tang H, Park S, Dhillon AS, Keller ET, Kolch W, Yeung KC: Snail is a repressor of RKIP transcription in metastatic prostate cancer cells. Oncogene 2008, 27:2243-2248.

65. Zhou BP, Deng J, Xia W, Xu J, Li YM, Gunduz M, Hung MC: Dual regulation of Snail by GSK-3beta-mediated phosphorylation in control of epithelial-mesenchymal transition. Nat Cell Biol 2004, 6:931-940.

66. Yang Z, Rayala S, Nguyen D, Vadlamudi RK, Chen S, Kumar R: Pak1 phosphorylation of snail, a master regulator of epithelial-to-mesenchyme transition, modulates snail's subcellular localization and functions. Cancer Res 2005, 65:3179-3184.

67. Wu Y, Deng J, Rychahou PG, Qiu S, Evers BM, Zhou BP: Stabilization of snail by NF-kappaB is required for inflammation-induced cell migration and invasion. Cancer Cell 2009, 15:416-428.

68. Roy HK, Kunte DP, Koetsier JL, Hart J, Kim YL, Liu Y, Bissonnette M, Goldberg M, Backman V, Wali RK: Chemoprevention of colon carcinogenesis by polyethylene glycol: suppression of epithelial proliferation via modulation of SNAIL/beta-catenin signaling. Mol Cancer Ther 2006, 5:2060-2069.

69. Gupta S, Adhami VM, Subbarayan M, MacLennan GT, Lewin JS, Hafeli UO, Fu $\mathrm{P}$, Mukhtar H: Suppression of prostate carcinogenesis by dietary supplementation of celecoxib in transgenic adenocarcinoma of the mouse prostate model. Cancer Res 2004, 64:3334-3343.

70. Raina K, Rajamanickam S, Singh RP, Deep G, Chittezhath M, Agarwal R: Stage-specific inhibitory effects and associated mechanisms of silibinin on tumor progression and metastasis in transgenic adenocarcinoma of the mouse prostate model. Cancer Res 2008, 68:6822-6830.

71. Harney AS, Meade TJ, LaBonne C: Targeted inactivation of Snail family EMT regulatory factors by a Co(III)-Ebox conjugate. PLoS One 2012, 7:e32318.

72. Zi X, Feyes DK, Agarwal R: Anticarcinogenic effect of a flavonoid antioxidant, silymarin, in human breast cancer cells MDA-MB 468: induction of G1 arrest through an increase in Cip1/p21 concomitant with a decrease in kinase activity of cyclin-dependent kinases and associated cyclins. Clin Cancer Res 1998, 4:1055-1064.

73. Kaur M, Velmurugan B, Tyagi A, Deep G, Katiyar S, Agarwal C, Agarwal R: Silibinin suppresses growth and induces apoptotic death of human colorectal carcinoma LoVo cells in culture and tumor xenograft. $\mathrm{Mol}$ Cancer Ther 2009, 8:2366-2374.

74. Singh RP, Deep G, Chittezhath M, Kaur M, Dwyer-Nield LD, Malkinson AM, Agarwal R: Effect of silibinin on the growth and progression of primary lung tumors in mice. J Natl Cancer Inst 2006, 98:846-855.

doi:10.1186/1476-4598-13-37

Cite this article as: Deep et al:: SNAI1 is critical for the aggressiveness of prostate cancer cells with low E-cadherin. Molecular Cancer 2014 13:37.

\section{Submit your next manuscript to BioMed Central and take full advantage of:}

- Convenient online submission

- Thorough peer review

- No space constraints or color figure charges

- Immediate publication on acceptance

- Inclusion in PubMed, CAS, Scopus and Google Scholar

- Research which is freely available for redistribution

Submit your manuscript at www.biomedcentral.com/submit
C Biomed Central 